\title{
Racine's Phèdre and the "Theatre of the World"
}

\section{Philip Knight}

Racine's Phèdre is a grand spectacle of French "classical" culture under Louis XIV. It is a highly refined theatre of "neo-classical" form and ethos, closely based on the "classical" tragedies of Euripides and Seneca, which also stages tensions in religion and social order in the world of Louis XIV, the "classical" period for the French. This essay will look at the play's central moment (where Phèdre fully confronts her guilt), using work on Louis' official culture and my own suggestions about the theatrum mundi (Theatre of the World) figure to read its political and religious meanings in new ways.

Louis had "fabricated" himself as a new kind of absolute monarch, the Sun-King officially in complete control of his society and its culture. 'In Marin's or Pickstock's account of this, society becomes a "theatrical city," "the king's stage," where he is both supreme spectacle and supreme spectator: while the Sun-King's "bedazzled subjects" gaze at him, they are "doubly gazed upon" by him. ${ }^{2}$ But this society which used the pagan/classical imagery of the Sun God Apollo in the service of absolute royal power, was also officially and often devoutly Catholic in belief. And just as Louis' style of kingship tended to reduce the dignity or freedom of action of his subjects, so there were similar tendencies at work within French Catholicism at the same time. The Jansenist movement insisted that all human beings are absolutely corrupt before God's grace, and without it lack dignity and free-will: all are worthless before the hidden God who sees all and will finally judge us. Although the King and the Jansenists were politically in conflict (and Louis XIV was to try to destroy them altogether just before he died), the monarchist and

\footnotetext{
${ }^{1}$ For an account of power and cultural representation under Louis XIV, see Louis Marin, Portrait of the King (London: Macmillan Press, 1988), J. P. Néraudau, L'Olympe du Roi-Soleil: Mythologie et idéologie royale au Grand Siècle (Paris: Les Belles Lettres, 1986), Peter Burke, The Fabrication of Louis XIV (New Haven: Yale University Press, 1992), Kathryn A. Hoffmann, Society of Pleasures: Interdisciplinary Readings in Pleasure and Power during the Reign of Louis XIV (New York: St. Martin's Press, 1997).

${ }^{2}$ See Marin (n. 1 above), 66-69, and Catherine Pickstock, After Writing: On the Liturgical Consummation of Philosophy (Oxford: Blackwell, 1998), 85-88.
} 
Jansenist cultures both preached a supreme spectator judge, whether god-like king or king-like God.

Racine had been brought up almost entirely by the Jansenist leaders and only lost contact with them when he opted for a career in the theatre, which they fiercely condemned. From early adulthood he had associated himself with the young Louis (who was about the same age), and paid his dues to royalist culture, early receiving payments from the king as an approved state artist. ${ }^{3}$ In 1677, just after writing Phèdre, he left the theatre to become full-time royal historian, and returned to the practice of Jansenist-tinged Catholic faith. Fancifully one might say he was, after Phèdre, exchanging the judgement of his theatre public for that of his God and his King.

However it may relate to Racine's personal decisions at the time, Phèdre is a play haunted by the sense that one cannot escape judgement. ${ }^{4}$ Fatality controls the story, of course, as in both the classical sources: for Euripides the revenge of Aphrodite, and for Seneca a more generalised sense of predestined evil. Racine has further intensified the atmosphere of doom, inescapable horror and monstrousness in the story, by using every resource of metaphor and mythical allusion in his poetic language. He employs the neoclassical rules to the same effect. The stage becomes a threatened and threatening space, time is heavy with fatality, and every action and word presses the story closer to catastrophe. The play's characters look in this way like "pawns of fate," or "prawns of fate" (as a student once put it in an exam) caught up in a net of events that leaves them no freedom.

Yet the characters are at the same time presented as independent moral agents, responsible for judging the rights and wrongs of political and moral action, and for self-judgement in their own conscience. The issue of judgement in the play centres on King Thésée. While he was thought dead both Hippolyte and Phèdre have acted as if in freedom, but when he returns everyone must meet his judging gaze, and he emphasises his status as avenging judge: "Let us

\footnotetext{
${ }^{3}$ See Jean Dubu, Racine aux miroirs (Paris: SEDES, 1992), 29-40, 81-92, 299310.

${ }^{4}$ Ibid., 217-30: "De quelques raisons esthétiques du silence de Racine après Phèdre."
} 
discover both criminal and crime"5 (line 986). This royal judge will misjudge both criminal and crime, but in a way that leads to the final uncovering of all hearts, in which all innocence and guilt are properly attributed. When at the end of the play the King surveys the scene with the other main survivor, Hippolyte's beloved Aricie, he knows finally that Oenone was guilty of abetting Phèdre's adulterous and incestuous desire for Hippolyte, and pushed the Queen into criminally accusing her step-son of approaching her. The King also knows for certain that Hippolyte was innocent and Phèdre guilty throughout-his original judgement was wrong, and caused his son's death. But he knows this because Queen Phèdre has appeared on stage at the final moment-having already taken poison-to confess her guilt (and Oenone's part in it) without excuses.

Phèdre has, however, confessed her guilt to Oenone (and the audience) very early in the play, and has gone on doing so at key points throughout. Although she presents her forbidden love for Hippolyte as "fated," fatally influenced by the vengeful Aphrodite, she invokes this sense of divine predestination not to excuse herself but to insist just how guilty she is. I want to concentrate here on the moment when Phèdre is most intensely aware of her personal guilt. In what are perhaps the climactic scenes of her tragedy (act 4, scenes 4, 5 and 6) she learns with horror of Hippolyte's love for Aricie, laments the new depths of suffering this causes her, rages in "transports of jealousy" (line 1263) about the young lovers, and even thinks of having Aricie killed. In a sudden access of self-judgement she realises her real moral position in one of the most extraordinary speeches in theatre. Knowing that now "the measure of [her] crimes is full" (line 1269) she sees herself standing alone before the universe:

Wretch! [Misérable!] And I live and can endure the gaze

Of the most sacred sun from which I spring?

My grandsire is the father and master of all the gods;

My forebears fill the sky, the universe.

Where can I hide? In dark infernal night?

No, there my father holds the urn of doom. (lines 1273-77)

5 English translations of Racine's incomparable verse follow those found in Jean Racine, Iphigenia. Phaedra. Athaliah, trans. and intro. John Cairncross (Harmondsworth: Penguin Books, 1987), slightly adapted on occasion by myself. 
$[\ldots]$

To see before him his own daughter stand,

[...]

What, father, will you say to that sad spectacle? (lines 1283, 1285)

Here between light and dark, height and depth, past and future, Phèdre's ancestors gaze at her, and judge her. The whole universe is full of spectators who see her for what she is: the Sun, Zeus/Jupiter the King and Father of the gods, and her father Minos as judge of the underworld kingdom of the dead. Under their scrutiny she cannot hide her sinfulness: her truth is exposed. Thésée's return from the dead to judge his family's conduct was a mere foretaste of this moment of absolute judgement.

A later moment in the play, moreover, echoes this scene. When Hippolyte goes to Aricie to ask her to accompany him into exile (V.1), she agrees to leave only if marriage is promised. Hippolyte proposes that they meet just outside Troezen at a "shrine dreaded by perjurers" for there "mortals never swear an oath in vain" (lines 1394-95). This is a place where only complete truthfulness is at home (as lines 1396-98 repeat insistently), and it is here Hippolyte proposes they swear their love:

We will take to witness this old temple's god;

We'll pray him to be father of us both.

I'll call to witness the most sacred gods,

And chaste Diana, Juno the august,

And all the gods, witnesses of my love,

Will lend their blessing to my holy love. (lines 1399-1405)

Here too, then, is human truth under the scrutiny of divine spectators, ready to judge moral worth and capable of sanctioning human failure. While Phèdre in the earlier scene was aware of judges condemning her, Hippolyte is on the other hand sure of his virtue and the truth of his vows. This contrast reveals the absolute difference between guilty and innocent, and thus confirms the official morality of the play. And where the judges of Phèdre are powerful fatherfigures, those of Hippolyte are the nameless (male) god of the temple, the two goddesses Diana (chastity) and Juno (marriage), and "all the gods" (mentioned twice). Both scenes, however, share the same structure: a human is under judgement, before divine and cosmic 
witnesses. Taking these scenes together, we can perhaps read the ideology of the play in new ways.

These sites of judgement have obvious correlatives in various aspects of seventeenth-century culture.

In terms of paternalist values (the absolute right of father over children), there is a clear contrast between the two "courts" of judges. Phèdre, subject to her paternal judges, knows how they will judge her failure as daughter and descendant to uphold family honour. Hippolyte in contrast does not include paternal gods amongst his judges, no doubt because he has been unjustly banished from his father's presence: he appeals mostly to goddesses representing "family values," guarantors of a more wholesome marriage and family than Thésée's, and he plans to ask the unnamed god of the temple to "be father to us both." The two "courts" have, too, clear legal implications, at the heart of a play where rhetorical persuasiveness is the typical mode of interaction between characters, and where debate about the rightness of an action or someone's guilt or innocence is often conducted in semi-legal terminology. ${ }^{6}$ Thus the language of judging (crime, criminal, innocent, unjust, etc.) points to a general imperative in the play: every character must judge and be judged. When Thésée returns to judge his subjects he judges badly, and both Phèdre and Hippolyte must therefore appeal to a higher court, composed of divine ancestors or gods of virtue. Before these judges they are sure of true justice, either fearing it (like Phèdre), or expecting moral vindication (like Hippolyte). The two moments of judgement must of course be read against the culture of absolute monarchy. Phèdre's court is composed of figures each of whom is in some sense a father, a judge, and a king, combining the attributes of kingly absolutism, while Hippolyte's judges are neither kings nor fathers. Rejected by Thésée, he is now fatherless and stateless, almost outside known social bounds, with no king or powerful god to protect him, while Phèdre still acknowledges divine kingship and will ultimately confess to the human king Thésée.

Besides, the two scenes of judgement differ completely in their theological resonances. Given the play's Greek setting and its preChristian classical sources, the divine judges of Phèdre and Hippolyte

6 See Michael Hawcroft, Word as Action: Racine, Rhetoric and Theatrical Language (Oxford: Clarendon Press, 1992). See also the fine rhetorical commentary in Richard Parish's edition of Phèdre (London: Bristol Classical Press, 1996), 57-110. 
are pagan deities. ${ }^{7}$ For Racine's audience, however, Phèdre's judgement scene in particular could no doubt also be understood in a Christian context. The spectators would know the traditional Catholic requiem hymn Dies irae which laments the Day of Wrath, the moment when each human must appear before God at the Last Judgement:

Then the judge will sit, revealing

Every hidden thought and feeling.

$[\ldots]$

What shall wretched I be crying

$[\ldots]$

When the just in fear are sighing?

King of tremendous majesty,

[...]

Save me then, o fount of piety. ${ }^{8}$

[Set to music, this was a favourite court funeral piece at Louis' court, as was the De Profundis, including these lines: "If you O Lord insist on gazing on our sins, O Lord who shall survive it?"]

The Christian sinner trembles before God's justice as Phèdre before her heavenly ancestors. Her judges (the Sun God, Jupiter and Minos) collectively correspond to the God of the Catholic hymn much more closely than do Hippolyte's gods and goddesses: while her judges are establishing her final guilt, his are endorsing sexual uprightness and promise-keeping. Phèdre is certain of her condemnation, Hippolyte convinced of his virtue.

Phèdre's vision of final judgement is closer to Catholic theology, and particularly to Jansenist thinking. This would find her profound awareness of personal corruption and self-condemnation appropriate not merely for a wrongdoer like Phèdre but for every human individual, each one a corrupt sinner damned unless God's grace intervenes. Phèdre's judgement of herself is the correct Jansenist one for a human being "to whom grace [is] not vouchsafed." Hippolyte's

\footnotetext{
${ }^{7}$ Racine uses the Greek gods' Roman names following contemporary practice.

8 Sequence for the Mass of All Souls in the pre-Vatican II Roman Missal: translation from The Small Missal (London: Burns and Oates, 1959), 414-15.

9 The Jansenist Arnauld described Racine's character Phèdre in these terms, if Racine's son is to be believed. See Louis Racine, "Mémoires contenant quelques
} 
complacent sense of his own virtue must seem in these terms only illusory self-love, a merely human pride, as if calling for general approbation of his virtue. For the Jansenist nun Mother Angélique de Sainte-Madelaine, the person "who is not satisfied with God alone as witness to his actions is too ambitious,"10 and Phèdre stands penitent and alone before the divine gaze of her judges.

Phèdre is aware of these judges as spectators only in a moment of spiritual insight, as it were. Unlike the Euripidean goddesses, who appear on stage, they are hidden from normal view. They remind us of the Jansenist Pascal's menacing sense of the "hidden God" (Deus absconditus) watching and judging human actions. ${ }^{11}$ I suggest that they also recall the traditional topos of human beings performing on the stage of the world, acting out their lives before the supreme spectator, God. This medieval commonplace, known as the theatrum mundi or Theatre of the World figure, had often been associated with tragedy. ${ }^{12}$ It had been used again in French Renaissance works like Pierre Boaistuau's Le Théâtre du Monde of $1558^{13}$, as an allegorical framework for the various "miseries" suffered by humanity, under a pitiless divine gaze. A sonnet by Baîf used as epigraph to that work puts it like this:

you call this life

The Theatre of the world, where the immortal Gods

Enjoy the sight of unfortunate mortals

Either laughing in Comedy, or lamenting in Tragedy.

[tu nommes cette vie

Le Théâtre du monde, où les Dieux immortels

Prennent plaisir de voir les malheureux mortels

particularités sur la vie et les ouvrages de Jean Racine," in Oeuvres complètes de Racine, vol. 1, ed. R. Picard (Paris: Gallimard, 1950), 49-50.

${ }^{10}$ Quoted by Lucien Goldmann, The Hidden God: A Study of Tragic Vision in the Pensées of Pascal and the Tragedies of Racine (London: Routledge and Kegan Paul, 1964), 1.

11 Goldmann, ibid., stresses that the "Hidden God" witnesses human tragedy in Racine, but he sees the Sun and Venus as representing God in this play, and does not pay sufficient attention to this judgement scene.

12 See Henry Ansgar Kelly, Ideas and Forms of Tragedy from Aristotle to the Middle Ages (Cambridge: Cambridge University Press, 1993), 56-57, 80-81.

13 Pierre Boiastuau, Le Théâtre du Monde, ed. Michel Simonin (Genève: Droz, 1981), 51 . 
Ou rire en Comédie, ou plaindre en Tragédie.]

For England, the Shakespearean echoes will be clear, while the Christian form of the figure (with God as spectator and final judge of each sinner's life at the Last Day) was used between 1640 and 1655 by English Puritan writers who (like the Jansenists) were opposed to the public theatre itself. ${ }^{14}$ In Catholic Europe the second half of the seventeenth century seems to have been particularly fixated on the "Last Things," and in particular the Day of Judgement. ${ }^{15}$ In seventeenth-century Spain the "Theatre of the World" allegory was fully Catholicised by the great Calderón de la Barca in his "sacramental" play of 1649 El Gran Teatro del Mundo, where the world is the stage, humans the actors, and God the author, director, spectator and judge of the play. ${ }^{16}$ Spanish theatre was well known in France around 1660 at the beginning of Racine's career: Calderón was especially popular ${ }^{17}$ and various Spanish types of "metatheatre," using analogies between theatre and life, had been adapted in France during Racine's lifetime. ${ }^{18}$ Racine is not working without precedent when he uses the theatrum mundi allegory to show Phèdre as a sinner supremely aware of herself as a "spectacle horrible" (line 1285)

14 See G. F. Waller, "The Popularisation of Calvinism: Thomas Beard's The Theatre of God's Judgements," Theology, vol. LXXXV, no. 622 (April 1972): 176-87.

15 Piero Camporesi, The Fear of Hell: Images of Damnation and Salvation in Early Modern Europe, trans. Lucinda Byatt (Cambridge: Polity Press, 1990), 105.

${ }^{16}$ See A. Parker, The Allegorical Drama of Calderón (Oxford: Dolphin, 1968), 116-20.

${ }^{17}$ See A. Cioranescu, "Calderón y el teatro clásico frances," in H. W. Sullivan, R. A. Galoppi and M. L. Stoutz, La comedia española y el teatro europeo del siglo XVII (London: Tamesis, 1999), 43.

18 Theatrum Mundi: Götter, Gott und Spielleiter im Drama von der Antike bis zur Gegenwart, ed. F. Link and G. Niggle (Berlin: Duncker and Humblot, 1981). Here Calderón's El gran teatro del mundo, is called the central "Instanz" (1): see especially the chapter by Reinhard Klesczewski: "Schauspieler und Regisseure im französischen Barockdrama," 177-98. See also Catherine Larson, "Metatheater and the Comedia: Past, Present and Future," in The Golden Age Comedia: Text. Theory and Performance, ed. Charles Gordon and Howard Manard (West Lafayette, Ind.: Purdue University Press, 1994), 204-21. 
before the divine gaze of judgement, in an anticipation of her eternal fate.

Racine has, then, set this scene of judgement in his tragedy like a play-within-a-play, the Theatre of the World inscribed within a particular tragic play. This small scene within a larger play is, though, a macrocosm within a microcosm, as the tragic theatre seems to open up for a moment into the ultimate "theatre" before the divine audience, the scene awaiting not only Phèdre but all humankind. So the spectators of the play looking at the divine gaze looking at a notable sinner confessing her sin, are to remember that each spectator, each individually guilty of sin, will also become a "horrible spectacle" before the God of judgement. It is as if Racine is trying to show that tragedy can be "true to life" (vraisemblable) not only according to the neo-classical rules but in a (Jansenist) Christian and moral sense. Certainly Phèdre's own view of her sinfulness at this theatrical moment is endorsed by the tragedy as a whole.

Phèdre's final achievement of abject total honesty before the hidden God contrasts with Hippolyte's proudly imagined human truthfulness almost as the stark Jansenist vision contrasts with the more "humanist" moderation of their Jesuit opponents. Phèdre's consciousness of herself as absolutely sinful makes her a suitable representative of humanity in Jansenist terms, and in this way (as in others) the play certainly evokes the Jansenist view of human nature and life in all its poetic and tragic power. It can be no coincidence that this play, more Jansenist in tone than any other of his plays, preceded Racine's renunciation of public theatre and his reconciliation with Port-Royal only by several months.

But Phèdre is also the last play he wrote before becoming, later in 1677, a full-time courtier at Versailles, in the post of Royal Historian which crowned his career as a cultural worker for the Sun-King. And in Phèdre's judgement scene, her judges are gods, but also two kings-Zeus, and Minos-and the Sun. Given the importance of the Sun as the key emblem of Louis XIV's cultural absolutism, it is tempting to read this scene in the light of it. Racine's public loyalty to the all-seeing King was, at least publicly, quite consistent. He would never, apparently, need to be reminded, as the politically suspect La Fontaine was in 1684, of the need to "[w]ork for the glory of the Prince, [...] under the eyes of a Prince who will keep himself 
informed of the progress you make in the ways of virtue." ${ }^{\prime 19}$ For this society, Louis was not only King but (in some sense) supreme Judge shining a divinely perceptive light into the conscience of his subjects. As the Sun-King/Apollo, he could say (as the Jesuit Lemoyne put it in the propaganda poem $L$ 'Art de Régner in 1665): "Je porte l'oeil à tout, mais un oeil éclairant, / Qui jamais ne prendra le vray pour l'apparent. $" 20$ This is the all-seeing Louis who intervenes at the end of two of Molière's plays (L'Impromptu de Versailles of 1663 and Tartuffe of 1669), in the latter to judge true behaviour and punish wrongdoing. In these plays the King's god-like powers as supreme judge are revealed in relation to a play-within-a-play, almost like the God-Author-Judge of Calderón's Great Theatre of the World. In the judgement scene of the model Jansenist sinner Phèdre in 1677, the judges are the Sun, the King of the Gods (Jupiter), and Minos the King/Judge of the dead. How is this to be read against the absolutist imagery of Louis' reign? Is it yet another reminder that the king judges all hearts? Is Racine appealing to Louis to judge Jansenism more benevolently? Or is there a hint of some more subversive reading here?

The "real" king in Racine's play is of course Thésée, husband of Phèdre, father of Hippolyte. In the play he at first judges Hippolyte guilty and Phèdre innocent, when the reverse is true: he is not allseeing, and his misjudgement is tragic. His moral character is doubtful too: while certainly a noble warrior hero, he also has a history of serial adultery, which counterpoints Phèdre's own adulterous desires. Now tragic dramatists and theorists in this culture of royalist absolutism were embarrassed at the way ancient and medieval traditions of tragedy showed kings and royal persons making mistakes and deserving punishment. Thus the greatest French neo-classical critic D'Aubignac admits that contemporary respect for royalty "will not allow us to give the public such spectacles full of

19 Reception speech by the Abbé Cureau de la Chambre, quoted in Marc Fumaroli, Le Poète et le Roi: Jean de La Fontaine en son siècle (Paris: Fallois, 1997), 12, 34-35.

${ }^{20}$ Quoted by Marc Fumaroli, "Microcosme comique et macrocosme solaire: Molière, Louis XIV et l'Impromptu de Versailles," Revue des sciences humaines, XXXVII, no. 145 (1972): 95-114. 
horrors" as did ancient tragedies. ${ }^{21}$ When Racine follows his classical sources in the characterisation of Thésée and Phèdre he confronts similar problems, and risks undermining the theory of absolute kingship. While the play ends with Thésée restoring order and justice in Sun-King fashion, it has depicted a king of doubtful sexual virtue, and a king too quick to condemn unjustly. How could the audience not remember Louis' many mistresses, and his overturning of his minister Fouquet in 1661 (for many the unforgettable opening injustice of his personal reign).

In this play there are in fact two opposing versions of kingship. The god-kings of Phèdre's judgement scene represent true all-seeing justice, whereas King Thésée is neither fully virtuous nor a competent judge. The tragedy plays these two types against each other, as if to say that even if the "real" king is less than perfect, divine judging kingship is after all the deepest reality of the universe. Just as in the Jansenist Augustinian system there are two aspects to life-the City of God and the City of Man-so there are two levels to the Theatre of the World: that of the all-seeing divine judgement (above), and that of less omniscient human kingship (below). The play voices the ideology of the Sun-King (which claims he is godlike) while allowing for questions about a real human king's practice. This is a tragedy carefully based on unassailable canonical models of theatre (Euripides, Seneca, and neo-classical tragic theory) which offers a site for potentially subversive reflection. Racine's last public work gives his spectators a theatre of the world of Louis XIV and of the world in which the divine is the final spectator and judge-a theatre which calls its audience both to judge and to be judged.

${ }^{21}$ Quoted by John D. Lyons, "The Barbarous Ancients: French Classical Poetics and the Attack on Greek Tragedy," Modern Language Notes 110, no. 5 (Dec. 1995): 1135 . 